


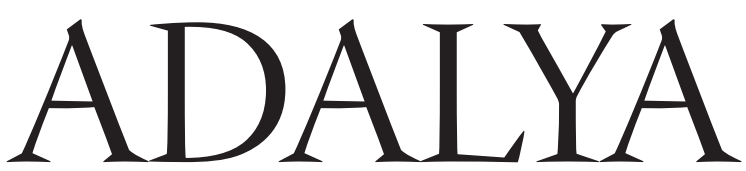

The Annual of the Koç University Suna \& İnan Kıraç Research Center for Mediterranean Civilizations

(OFFPRINT) 


\section{ADALYA}

The Annual of the Koç University Suna \& İnan Kıraç Research Center for Mediterranean Civilizations (AKMED)

Mode of publication

Adalya, a peer reviewed publication, is indexed in the A\&HCI

(Arts \& Humanities Citation Index) and CC/A\&H (Current Contents / Arts \& Humanities)

Adalya is also indexed in the Social Sciences and Humanities Database of TÜBİTAK/ULAKBIM TR index and EBSCO.

Publisher certificate number

Worldwide periodical

18318

ISSN 1301-2746

Publisher management

Koç University

Rumelifeneri Yolu, 34450 Sariyer / İstanbul

Publisher Umran Savaș İnan, President, on behalf of Koç University

Editor-in-chief Oğuz Tekin

Editors Tarkan Kahya and Arif Yacı

English copyediting Mark Wilson

Editorial Advisory Board (Members serve for a period of five years)

Prof. Dr. Mustafa Adak, Akdeniz University (2018-2022)

Prof. Dr. Engin Akyürek, Koç University (2018-2022)

Prof. Dr. Nicholas D. Cahill, University of Wisconsin-Madison (2018-2022)

Prof. Dr. Edhem Eldem, Boğaziçi University / Collège de France (2018-2022)

Prof. Dr. Mehmet Özdoğan, Emeritus, Istanbul University (2016-2020)

Prof. Dr. C. Brian Rose, University of Pennsylvania (2018-2022)

Prof. Dr. Charlotte Roueché, Emerita, King's College London (2019-2023)

Prof. Dr. Christof Schuler, DAI München (2017-2021)

Prof. Dr. R. R. R. Smith, University of Oxford (2016-2020)

(c) Koç University AKMED, 2020

Production Zero Production Ltd.

Abdullah Sok. No. 17 Taksim 34433 İstanbul

Tel: +90 (212) 2447521 • Fax: +90 (212) 2443209

info@zerobooksonline.com; www.zerobooksonline.com

Printing Fotokitap Fotoğraf Ürünleri Paz. ve Tic. Ltd. Şti.

Oruç Reis Mah. Tekstilkent B-5 Blok No: 10-AH111

Esenler - İstanbul / Turkey

Certificate number: 47448

Mailing address

Barbaros Mah. Kocatepe Sok. No. 22

Kaleiçi 07100 Antalya - TURKEY

Tel: +90 (242) 24342 74 • Fax: +90 (242) 2438013

https://akmed.ku.edu.tr

E-mail address $\quad$ adalya@ku.edu.tr 


\section{Contents}

Burçin Erdoğu

Capturing the Seen and Unseen in the Beldibi Rock Art .. 1

Özlem Çevik - Murat Dirican - Aydın Ulubey - Osman Vuruşkan

The Galena Objects from Neolithic Ulucak: The Earliest Metallic Finds in Western Turkey 7

Abdullah Hacar - K. Aslıhan Yener

Anatolian Pot Marks in the 3rd Millennium BC: Signage, Early State Formation, and

Organization of Production 25

A. Tuba Ökse

Reflection on the Sunrise Positions in Early and Middle Bronze Age Extramural

Cemeteries in Anatolia 59

Sevgül Çilingir Cesur

The Timing of Ritual Performance in Hittite Texts: The "Morning" Rites 87

Dries Daems

Reassessing the Origin of Polis in Lycia and Southwest Anatolia 111

Fatma Şahin - Erkan Alkaç

Banded Bowls from Tepebağ Höyük (Cilicia Pedias)

Özgün Kasar - Kaan İren

Leaded Bronze Arrowheads at Daskyleion 175

Hazar Kaba

An Elite Tomb from Soloi: New Evidence for the Funerary Archaeology of Cyprus

Erkan Alkaç - Ulus Tepebaş

The Gem Stamp on the Handle of a Mushroom-rimmed Amphora from Knidos:

An Assessment of the Centauromachy in Terms of Stamps and Iconography

Hüseyin Sami Öztürk - Ögül Emre Öncü

Olympos in Lycia: A Novel Assessment of its History and Localization in Light of Recent

Archaeological and Epigraphical Research

Nihal Tüner Önen

Two New Inscriptions from the Claudian Period at Perge 277

Handegül Canlı

A Unique Roman Folding Knife Handle with Eagle Ornament from Philadelphia in Cilicia 289 
Şenkal Kileci - Birol Can

A New Honorific Inscription from Blaundos: Tiberius Claudius Lucius, the Priest of

Dionysos Kathegemon

Ahmet Tolga Tek - Hacer Sancaktar

A Numismatic Riddle from Arykanda: The God of the Water Spring .

Mark Wilson

The Discovery of a Menorah in Attalia (Kaleiçi, Antalya) and its Significance for

Jewish Communities in Pamphylia

Özgü Çömezoğlu Uzbek

A North African Plate Unearthed in the Andriake Excavations

Philip Bes

Early Byzantine Pottery from Limyra's West and East Gate Excavations

Nilgün Elam

Ecclesiastical Personages of Side ( $\Sigma i \delta \eta$ ) of Pamphylia according to Literary and Sphragistic Data

Ömür Bakırer

Window Glass from the Excavations in the Seljuk Palace at Alanya

Mahmut Demir - Terrance Michael Patrick Duggan - Erkan Kurul

Observations and Assessments of Some Epigraphic Graffiti Found on Entrances in

Kaleiçi/Antalya

Ayşe Ozil

A Traveller in One's Homeland: Local Interest in Archaeology and Travel Writing in the

Ottoman Greek World in 19th Century Anatolia

Alex Rodriguez Suarez

Two Church Bells from Antalya: Traces of the Religious Soundscape of the Late Ottoman Period 517 


\title{
A North African Plate Unearthed in the Andriake Excavations
}

\author{
ÖZGÜ ÇÖMEZOĞLU UZBEK*
}

\begin{abstract}
Twelve fragments constitute the subject of this article, one of which is part of a body and eleven are parts of borders.

Six fragments (figs. 2, 4/a-f, 5) belong to the longer border of a rectangular plate. A corner fragment shows a bearded, nude figure with open arms standing inside a kantharos. Along the border is a running lion figure. The remaining section shows a standing figure (Lazarus) wrapped inside an aedicula with a triangular pediment. Six different fragments (figs. 3/g-1, 6, 7) are distinguished by their clay composition but represent the same decorative motifs. Behind a lion there appears part of a triangular pediment. Additionally, a section of a lion's mane, the body of a running lion, and the lower part of a kantharos are discernible. A small fragment shows a part of a horse's head and body along with an inscription. The central decoration must be a depiction of the Dioscuri.
\end{abstract}

These fragments belong to plates manufactured in North Africa. This type is dated between the years AD 360 and 430. However, the dating could be extended to the late 5th century up to early 6th century $\mathrm{AD}$. We can propose a period between the second half of the 4th century and the early 6th century AD.

Keywords: Andriake, Lycia, Late Roman ceramics, North African ceramics

\section{Öz}

Bu makalenin konusunu oluşturan toplam 12 parçadan biri gövde, on biri kenar fragmanıdır. Hamur ve astar kalitelerine bakıldığında belki bir değil, aynı kalıbın kullanıldığ 1 iki tabak olabileceği düşünülmektedir.

Birleşen altı parça (fig. 2, 4/a-f, 5) dikdörtgen bir tabağın uzun kenarına aittir. Köşeye gelen kısımda, kantharos içinde çıplak tasvir edilmiş sakallı, kollarını iki yana açmış bir figür bulunmaktadır. Bordürün devamında koşan bir arslan figürü; geri kalan kısmındaysa üçgen alınlıklı aedicula içinde kumaşa sarınmış ayakta duran bir figür (Lazarus) bulunmaktadır. Farklı altı parça ise (fig. 3/g-l, fig. 6, 7) hamur yapilarıyla ayrilır ancak aynı bezeme motiflerini içerirler. Bir arslanın arkasına denk gelen kısımda bir üçgen alınlık parçası görülmektedir. Ayrıca arslan yelesine ait bir bölüm; koşan bir arslanın gövdesi; bir kantharos'un alt kısmı tanımlanabilmektedir. Orta tablanın küçük parçasındaysa, bir atın kısmen baş ve gövdesi ile başının üzerindeki yazıta ait bölüm görülebilmektedir. Andriake'deki tabakla aynı konuya sahip benzerleri incelendiğinde, merkezdeki bezemenin Dioskurlar tasviri olduğu öne sürülebilmektedir.

Parçalar, Kuzey Afrika'da üretilen tabakların Andriake'ye ulaşmıs örneklerine ait olmalıdır. En bilinen sinfflamayla Hayes form 56 grubunun örnekleridir. Bu tip MS 360 ile 430 y1lları arasina tarihlendirilse de, bu tarihleme MS 5. yüzyıl sonlarıyla 6. yüzyıl başlarına kadar esneyebilmektedir. Buluntularımız için MS 4. yüzyılın ikinci yarısı ile en geç 6 . yüzyılın başları arasinda bir tarih önerebilmekteyiz.

Anahtar Kelimeler: Andriake, Lykia, Geç Roma seramikleri, Kuzey Afrika seramikleri

* Assoc. Dr. Özgü Çömezoğlu Uzbek, İstanbul Üniversitesi, Edebiyat Fakültesi, Sanat Tarihi Bölümü, Fatih, İstanbul, Türkiye. E-mail: ozgu@istanbul.edu.tr ; https://orcid.org/0000-0002-8895-5084 


\section{Introduction}

A group of ceramic plate fragments with striking form and decorative characteristics was unearthed during the Andriake excavations in 2018. The fragments were the pieces of one or two rectangular plates with flat bases. A total of 12 fragments were found in the excavation site to the north of Church A in the southern settlement of the port of Andriake in a separate context from the structure (fig. 1).

The ceramics discussed in the article are the fragments of rectangular plates that were manufactured in North African workshops and then arrived in Andriake. They feature a part of a symbolic expression of the Dioscuri in the center, accompanied by depictions from Christianity and common motifs of the era on their rims. This type of ceramic plates was made not for daily use but custom-made for the owner. Very few comparanda have been identified in terms of subject matter and decorative elements. Rectangular ceramic plates with similar central depictions include comparanda at the Staatliche Museen zu Berlin and the Athens Benaki Museum, findings from Algeria/El Hadjeb (currently missing), and Algeria/Tiddis. Also, it is known that various subjects are addressed on North African plates. Fragments of this red slip ware from Andriake are among specific examples known as new findings.

The trays decorated on their center or on the rim are called lanx, Latin for "dish". Among the examples of the $\operatorname{lan} x$ there are oval, square, rectangular and polygonal forms. This is a vessel type to be used for the cult or to serve food. ${ }^{1}$ D. Buckton has distinguished a silver tray with the same term due to its form. ${ }^{2}$ Clay vessels like those found at Andriake have symbolic representations on both their center area and rim. As will be discussed below, these vessels were special gifts to high-level bureaucrats. The vessels are often distinguished as "plates" in the literature.

\section{Port of Andriake}

Andriake is a port settlement located 4.7 kilometers southwest of Myra in Demre, Antalya. The port was divided into northern and southern parts.

The earliest material data from Andriake are the ceramics dated to the 4th century BC. As one of the important ports of Lycia, Andriake must have been affected by the historical events of the area. In 333 BC Lycia was conquered by Alexander the Great. Following this, Ptolemaic domination started in Lycia after 306 BC. Andriake is mentioned among the cities that the Seleucid king, Antiochus III, occupied in 197 BC. ${ }^{3}$ In the following period Lycia came under Rhodian rule and later became independent in 167 BC. The existence of the Lycian Federation is reckoned from this date. At around $100 \mathrm{BC}$, Myra was one of the most important harbor cities of the Federation. At the same time it was a metropolis. ${ }^{4}$

Numismatic and architectural data indicates that the city was active from the Hellenistic period onwards. The towers and fortifications at the southern part indicates that the entrance to the harbor was controlled during the Hellenistic period. In the following period, an inscription of the customs law dated to AD 60-63 was erected during the reign of Emperor Nero. ${ }^{5}$

\footnotetext{
1 Delemen and Çokay Kepçe 2009, 15; Akkurnaz 2016, 135-35.

2 Buckton 1994, 38.

3 Çevik and Bulut 2010, 26; Magie 1950, 524.

4 Magie 1950, 519-20, 524, 528; Çevik and Bulut 2010, 26-27; Çevik et al. 2014, 233-34.

5 For the detailed examination of the inscription, see Takmer 2007.
} 
During his captivity journey in AD 60-61 Saint Paul transshipped to an Alexandrian ship in Andriake on his way to Rome. ${ }^{6}$ In the following years Christians began to have a significant influence in Lycia, particularly after Christianity was legalized in the early 4 th century. ${ }^{7}$ Saint Nicholas, the bishop of Myra, lived and died here in the 4th century, which made the city an important religious center. Myra was declared capital city of Lycia during the reign of Theodosius II (AD 408-450) and became the regional metropolis. Marine transportation was a chief factor in the development and significance of Andriake. The port of Andriake cannot be considered independent from Myra, the regional metropolis. Also, the fact that it is situated on an important trade route on the southwestern coast of Anatolia shows the importance of its location.

After an earthquake in AD 529, Emperor Justinian ordered a large-scale reconstruction in Myra. Also, the excavations at the Andriake churches have yielded data indicative of these repairs. The outbreak of a plague in AD 542 must have affected the city; however, the port was still active in the 6th century. The biography of Saint Nicholas of Sion, who died in AD 564, says that he used the port of Andriake for his journey to Jerusalem. ${ }^{8}$ Coins found in Andriake indicate a rejuvenation of the port city from the 4th century onwards, and the largest group of coin findings is from the 4th century.

From the mid-7th century onwards Lycia, along with other parts of Anatolia, was targeted by Arab attacks. The church of Saint Nicholas in Myra remained active until the 13th century, but it was buried by alluvium after the great flood in the middle of the 13th century. Myra was excluded from the episcopacy list in the 15th century. However, the excavations at Andriake found that the port became virtually inactive between the late 7 th century and the early 8th century. There is limited data from the subsequent periods. Except for a coin from the 11th century, the latest coin found in Andriake was dated to the middle of the 7th century (Constans II, AD 641-668). Although it is believed that the port of Andriake was still in use in the 10th-11th century, findings and numismatic data both support the hypothesis that the port was no longer heavily used after the late 7 th or early 8 th century. ${ }^{10}$

An agora and a granarium were built in Andriake during the reign of Emperor Hadrian. During his visit to Lycia, the emperor ordered granaries to be built at Andriake and Patara. ${ }^{11}$ The granarium was used until the early 7 th century at least. The agora was transformed into a murex dye workshop in the first half of the 5th century and used until the 7 th century. A wine workshop, active between the 4th and 6th centuries, was identified in front of the granarium. Shops built along the coast in the late 2 nd and early 3 rd centuries were used with annexes until the end of the 6th century. There were two bathhouses in the southern part, which had dockyards in the west. There was a synagogue, dated to the 5th-6th centuries, also in the southern settlement. ${ }^{12}$ There were a total of six churches in Andriake. Four of these churches were located in the southern settlement (Churches A, B, C and F), while the other two were

6 Çevik et al. 2014, 227-28.

7 Tekinalp 2001, 505, 507 n. 102.

8 Çevik and Bulut 2010, 28-29; Çevik et al. 2014, 228-29; Akyürek 2016, 469-70.

9 Bulut and Şengül 2010, 120; Aygün 2018, 164.

10 Çevik and Bulut 2010, 29; Bulut and Şengül 2010, 120-21; Çevik et al. 2014, 230.

11 Magie 1950, 620.

12 Çevik et al. 2010; Akyürek 2016, 474-75; Aygün 2018, 165-71. A master's thesis on murex dye workshops was prepared and published as a book; see Aygün 2016. 
in the northern settlement (Churches D and E). Except for church F, all churches have a threenaved basilica layout. ${ }^{13} \mathrm{M}$. Tekinalp groups these among 5 th-6th century churches by their dimensions and architectural arrangements, and proposes a date in the 5th century for the initial phases of the Andriake churches. ${ }^{14}$ It is also believed that outbuildings were put up for the churches in the 9th centuries and the 11th-12th centuries. ${ }^{15}$ The fact that there were six churches suggest that Andriake also provided services for pilgrims who came by sea to visit the grave of Saint Nicholas in Myra. ${ }^{16}$

\section{The Andriake Fragments and North African Plates}

The fragments mentioned in the introduction are examples from the group Hayes Form 56, according to the best-known classification. One fragment belongs to the base, and eleven are from the rim. The plate has a profiled rim and a flat center area (figs. 5, 7). No foot fragments were found. Clay and slip characteristics of the rim fragments suggest that they come from two plates made in the same mold rather than one plate. The orange/red clay contains a small amount of fine sand, has a slip of the same color, and very few pores. Six rim fragments can be assembled (figs. 2, 4, 5; fragments a-f). Assembled fragments give information on decorations on the rim. Those fragments are understood to have come from the longer side of a rectangular plate. A naked and bearded figure depicted inside a kantharos appears on the corner. The figure, in frontal view, spread his arms to each side. There is also a running lion figure on the border. The lion's mane, fur and body were decorated with linear lines. The remaining part of the border has a standing figure wrapped in cloth inside an aedicule with a triangular pediment. Two steps under the aedicule were decorated with a vegetative and geometric arrangement.

Clay of the other six examples has a softer texture, which suggests that these examples could have been fired separately from the other six mentioned above (fig. 3, fragments g-l, figs. 6, 7). The border, uniform with the first group, was decorated with the same theme. When assembled, two fragments create another running lion figure with characteristics identical to the lion of the first group (fig. 6 , fragments $\mathrm{g}, \mathrm{h}$ ). A piece of a triangular pediment appears behind the lion. Among the fragments (figs. 3, 6, fragments i, $j, \mathrm{k}$ ) one has a part of a lion's mane, another has the body of a running lion, and the last one shows the lower part of a kantharos.

Among these, a fragment from the base area gives important information about the central decorations of the plate (figs. 3, 6, fragment 1). This small fragment shows part of a horse's head and body, a part of an inscription above the head. Written in dual lines, the letters DOM can be discerned; however, the entire word is not legible. Based on another example with the same decoration, ${ }^{17}$ a depiction of the Dioscuri appears in the center. This comparison also yields information on the contents of the inscription of the Andriake plate.

According to the analysis of all of the fragments, it can be argued that they might have come from two separate plates if all of the lion figures with identical characteristics are from the longer borders. Based on the comparisons, it is possible to suggest that a long border has

\footnotetext{
13 For the churches' layout, see Tekinalp 2001.

14 Tekinalp 2000, 291-313; The researcher gives information on the previous datings of the churches; see Tekinalp 2001, 495; Tekinalp 2000, 289-90.

15 For proposals on the phases of church repairs, see Tekinalp 2001, 511-13.

16 Akyürek 2016, 477; Aygün 2018, 177-80.

17 For the example at the Benaki Museum, see Fotopoulos and Delivorrias 1997, no. 285.
} 
two lion figures running in different directions. However, three lion figures running in the same direction indicate three longer borders rather than two. Considering the difference in firing quality, it can be proposed that there are two plates made in the same mold.

The plates of similar types are vessels made in two-part molds with a foot added later. ${ }^{18}$ Many vessels of this type appear to have come from the same mold, but secondary motifs in some of them indicate the presence of secondary molds associated with them. There are longer and shorter versions based on the length of the rim in the same mold. This shows that the same series had variations. ${ }^{19}$

It is known that plaster or ceramic was used to make the positive models for motif molds. Analogs include plaster models and molds prepared for a plate with a depiction of Achilles' life and another with a depiction of Pegasus. In these models, rims rise in line with the angle of the plate. Also, these molds and models give information on the width of the square base. ${ }^{20}$

In Hayes Form 56 examples, base decorations are relief while rim border decorations are relief or applique. ${ }^{21}$ The same type was named African Sigillata groups C and D in different previous studies. Group C was decorated with relief and mold, and group D was decorated with mold. ${ }^{22}$

Similar to the Andriake plate, a plate found in Algeria/El Hadjeb (Mouzaiville) has depictions of 12 saints or apostles on the border, which indicates that plates with the same contents on the base can have different decorations on the rim border. ${ }^{23}$

The area of Tunisia and Carthage are included among the main production and distribution centers of African red slip ware (ARS). It is known that certain types of products were made in central and southern Tunisia. ${ }^{24}$ Salomonson proposes a production region in North Africa and Egypt based on the higher number of examples found in the area. ${ }^{25}$ The words "Mauritania" and "Africa" appear in the inscriptions on some vessels of the type, which is presumably indicative of their place of production. Algeria, Tunisia and Egypt are the most frequent findspots. Like the examples found in Spain, Italy and Austria, a number of examples from unknown places of production are included in the collections of museums in Germany and the Netherlands. ${ }^{26}$

One example found at Hadrianopolis (Albania) was analyzed and discovered to be a local production. Imitations of wide-rimmed African plates from the AD 4th to 6th centuries were found here. ${ }^{27}$

A period between AD 360 and 430 has been proposed for the rectangular plates with wide rim borders found in Carthage. But there are also other examples found in the context of the

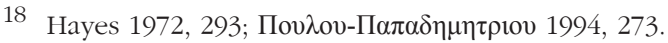

19 Hayes 1972, 293.

20 Garbsch 1989, 243-45.

21 Hayes 1972, 83-84.

22 Carandini and Tortorici 1981, 160.

23 Hayes 1972, 84, form 56d, no. 11.

24 Fulford and Peacock 1984, 111-12.

25 Salomonson 1969, 67.

26 Carandini and Tortorici 1981, 160-61.

27 Perna et al. 2010, 732, figs. 6-7. 
6th century. ${ }^{28}$ Hayes and Bailey mention the same period (AD 360-430) for the dating of such plates. ${ }^{29}$ Salomonson proposes the period between the last quarter of the 4th century AD and 430, when North Africa was conquered by the Vandals. ${ }^{30}$ Allais studied a plate of this type with a Pegasus depiction found in Djemila (el-Djem, Tunisia). A comparison between the medallions and coins on the rim showed that the plate could not be dated before the 4th century AD. Analysis of an analog with the same subject matter found in Tiddis in terms of the clothes and style of figure point to the same century. ${ }^{31}$

Mackensen proposes Sidi Marzouk in central Tunisia as the production center of these plates. ${ }^{32}$ The author proposes that the vessels with depictions from Christianity with applique and mold decorations can also be dated after $\mathrm{AD} 430$, in the second half of the 5th century and even later. ${ }^{33}$

A fragment among the examples found in Nicotera (Italy) has the depiction of a figure holding a spear. Also, a figure depicted in a kantharos on a border fragment has identical characteristics with the Andriake decorations (figs. 2, 4, fragments a, b). These examples found in Nicotera were compared to the type dated between AD 300 and 430. ${ }^{34}$

Few examples of plates with Dioscuri depictions, like the ones found in Andriake, have been discovered so far.

A horse with rider and a partial inscription are seen on one of the two examples at the Benaki Museum with Dioscuri depictions. The other example from the same museum shows Castor and Pollux with their horses in the center, with a kantharos between them. The inscription above reads: ORATIONIBVS SANTORVM PE/RDVUCET DOMINVS. A running lion, an aedicule with a figure in front of it, and a kantharos appear on the longer border of the rim. Only the top section of the central composition has survived. ${ }^{35}$ However, a fragment at the Berlin Staatliche Museum illuminated the missing part of these vessels at the Benaki Museum, and enabled a restoration. On the base, two figures in eastern garb (decorated tunics, slim and long pants, and a cape tied over the right shoulder) stand in front of their horses, facing each other. They hold the leads of their horses and have spears on their other hand. They have Phrygian caps, and there is a two-handled kantharos between them ${ }^{36}$ (fig. 8). There is a figure in front of an aedicule on the longer border of the rim. ${ }^{37}$ There are two lions facing different directions on the sides of the aedicule with one kantharos on each corner. Two panthers run in different directions on the short sides of the plate. ${ }^{38}$

28 Fulford and Peacock 1984, 80, 83.

29 Hayes 1972, 91; Bailey 1998, 2-3.

30 Salomonson 1962, 88; 1969, 14.

31 Allais 1959, 49-51.

32 Mackensen 2015, 198.

33 Mackensen 2004, 792, 804.

34 Cuteri et al. 2014, fig. 14.3a-3b, 4.

35 For the two examples at the Benaki Museum, see Salomonson 1962, pl. XXI.1, 2. Hayes also mentions the two examples at the Benaki Museum, and describes the extant plate with its rim borders; see Hayes 1972, 84-85, form 56d/no. 10. Also see Fotopoulos and Delivorrias 1997, 162, no. 285.

36 For the fragment in Berlin, see Salomonson 1962, pl. XXI.3. For the proposed restoration with these fragments, see Salomonson 1962, 68, fig. 4.

37 Garbsch designates the figure as a statue of Venus or a description of Lazarus, but Lazarus is likelier based on the figure's costume; see Garbsch 1980, 192.

38 Garbsch 1980, 192, fig. 21. 
Plate fragments found in Andriake could have a composition similar to the plates described above. However, the Andriake plate also has discernible figures inside the corner kantharos and a figure in front of the aedicule.

While another example found in El Hadjeb, Algeria, has the same depiction in the center, the figures on the rim, as mentioned above, are believed to be 12 saints or apostles. ${ }^{39}$ This example has the same inscription as the one on the Benaki Museum plate. A similar inscription is partially visible on a fragment found in Tiddis and Algeria too. ${ }^{40}$ Its content was obtained based on comparisons with the prayers read during rituals: "At the intersection of the Saints, the Lord will lead us (you) to the eternal joys of heaven."

Salomonson mentions that a kantharos is a symbol of happiness, and notes that the figures on both sides of the central kantharos are the Dioscuri. He also states that this depiction of Castor and Pollux with Phrygian caps is not unusual in the late Roman period. ${ }^{41}$

The Dioscuri symbolize day and night, life and death, in pagan belief. They were regarded as the personification of eternity and heaven, and entered Christian depictions as the symbol of eternity. For instance, there are depictions of the Dioscuri on two sides of a cross in the center of a round vessel in Marseille. The Dioscuri can be depicted in or out of a pagan context. ${ }^{42}$ The Dioscuri is the name given to Castor and Pollux, the twins of Zeus and Leda. Castor is mortal while Pollux is immortal. According to the myth, however, when Castor dies and Pollux is wounded, Zeus does not want to separate them and places both of them among the stars. ${ }^{43}$ The Dioscuri are depicted with their horses, and they survived the propagation of Christianity. They accompany scenes like the 12 Apostles, the arrest of Saint Peter, and the raising of Lazarus. They have been identified with pairs of saints, such as Peter and Paul or Cosmas and Damian, although the church rejects their immortality. ${ }^{44}$ Two eastern saints named Nearchus and Polyeuctus are known to replace Castor and Pollux. Around the Bosphorus, Pollux of the Dioscuri was identified with archangel Michael. ${ }^{45}$

Subject matters vary on the round or rectangular plates with wide rims made in North Africa, and they display similarities in decorative elements as well as their style. Mythological scenes, competitions at the hippodrome, hunting scenes, historical events, depictions of Christianity, and the Old and New Testaments are addressed. ${ }^{46}$ Also, the personifications of Carthage, Mauritania and Africa are seen on the bases of these plates made in North Africa. ${ }^{47}$ The running lion figure on the rim of a plate from Alexandria has similarities with the Andriake examples in terms of decoration. On an example with a Pegasus depiction found at Carnuntum, the work on wings of the Pegasus have quite similar details to the style on fragments of the plate

39 Hayes 1972, 84, form 56d, no. 11.

40 Salomonson 1962, 69-70. The transcription of the inscription on the El Hadjeb find, currently missing in the figure: "At the intersection of the Saints, the Lord will lead us (you) to the eternal joys of heaven."

41 Salomonson $1962,70$.

42 Salomonson $1962,71$.

43 Erhat 1989, 104-5.

44 Kazdhan and Talbot 1991, 633.

45 Harris 1906, 55-56, 131-34. Castor and Pollux are featured in the Argonaut story. The archangel Michael was identified with the eagle-like sacred entity that appears during the fight between Amycus, the king of Bebryces, and Pollux. This later led to the identification of Pollux with Michael. Churches devoted to the archangel are known to have existed on both sides of the strait; see Harris 1906, 131-34.

46 Поvגov-П $\alpha \pi \alpha \delta \eta \mu \eta \tau \rho ı v ~ 1994,274$; Cuteri et al. 2014, 71. For variations of the type. see Salomonson 1962; Hayes 1972, 83-91.

47 Salomonson 1969 , 6-7 n. 7. 
with the Dioscuri depiction found in Andriake. ${ }^{48}$ Another plate with a Pegasus depiction, also found in Djemila (el-Djem, Tunisia), has vines extending upward from a kantharos in the central decoration. This kantharos has similarities with the plate with the Dioscuri depiction found in Andriake. Allais points out that analogs of the kantharos are seen in churches with mosaics from the 4th-5th centuries. ${ }^{49}$ A similar depiction of lion figures is seen on another Pegasus plate in Cairo. An analogous lion depiction appears on a plate from Egypt in Heidelberg too. ${ }^{50}$

Border lengths and base dimensions of the plates found in Andriake are unknown. However, it is important to consider the information available on the dimensions of similar plates in order to gain insight on the sizes of these plates. A similar plate found in El Hadjeb, Algeria is $45 \times 37 \mathrm{~cm}$ in dimension. ${ }^{51}$ It has been reported that a plate with depictions of Achilles' life, currently in Munich, measures 44 x 34.5 x 4.5-5.5 cm. The example with Dioscuri depiction at the Benaki Museum in Athens is $46.5 \times 36.5 \mathrm{~cm}$ in size. ${ }^{52}$ Another model with Achilles depictions had a $31 \times 23 \mathrm{~cm}$ central base area, and a model with Pegasus depictions had a $30.3 \times 22.5 \mathrm{~cm}$ central base. ${ }^{53}$ Another plate found in Djemila (el-Djem, Tunisia) with a central Pegasus depiction is $48 \mathrm{x} 40 \mathrm{~cm}$ in size. ${ }^{54}$

\section{The Function and Origins of the Type}

These ceramic plates have similarities with silver plates made in the 4th-5th centuries. Salomonson points out the similarity between this type with relief decorations of consular diptychs in terms of decorative characteristics. He also draws a comparison with the silver plates given as gifts to high-level bureaucrats in the 4th-5th centuries in terms of technique, craftsmanship and form. He argues that ceramic examples were made as cheaper versions of these works. ${ }^{55}$ Garbsch mentions the similarities between metal and ceramic examples. However, there are differences in the dimensions and choices of figures depending on the vessel size. He points out that the clay Achilleus plate at Munich has close similarities with the silver Achilleus plate from the Kaiseraugst treasure. ${ }^{56}$ In particular, the silver Ariadne tablet and the Achilleus plate from the collection have many resemblances with the clay ones in shape and decoration. These silver plates are considered to be the ceremonial plates given as gifts to high-ranking officials. ${ }^{57}$ An oblong silver tray - the Corbridge lanx from the British Museum - has the representation of the shrine of Apollo on Delos. This object is similar to the clay plates in terms of its relief decoration and rectangular form. ${ }^{58}$

A consul with a mappa and a staff in his hands found in Carthage might have been copied from an ivory diptych dated to AD $428 .{ }^{59}$ It is suggested that these plates, which show

\footnotetext{
48 For the example at the Alexandria Graeco-Roman Museum, see Bailey 1998, pl. 2. For the plate found in Carnuntum and analogs, see Mackensen 2015, 198-99, 201, fig. 2.

49 Allais 1959, 51.

50 Salomonson 1962, 58, pls. XIII.1, XV.3, XXIII.1-2.

51 Salomonson 1962, 69.

52 Garbsch 1980, 155, fig. 21.

53 Garbsch 1989, 243-44.

54 Allais 1959, 44.

55 Allais 1959, 55.

56 Garbsch 1980, 158-59

57 Guggisberg 2003, 300, nos. 61, 63.

58 For detailed description of the lanx, see Buckton 1994, 36-38.

59 Mackensen 2004, 793.
} 
similarities with ivory diptychs and silver plates, were also inspired by them in terms of their subject matter.

According to the comparisons between diptychs and silver plates, it has been put forth that some of the plates could be objects presented on special days. Repair holes on ceramic versions indicate that they were important for the owners, who wanted to preserve these objects. ${ }^{60}$ Although made in mass production, the use of relief on interior surfaces show that they were not made for daily use so had a symbolic value.

\section{Conclusion}

As mentioned above, analogs of the plates found in Andriake in terms of iconography and style have been dated between AD 360 and 430. This period can be extended to the late 5 th century or even to the early 6th century AD. Our findings indicate a period between the second half of the 4th century and the early 6th century $\mathrm{AD}$ at the latest. Although they were found in an excavation site that contains late antique findings, their context does not give any more distinguishing clues regarding their date. Like their analogs found in other sites, these plates are understood to have been made in North Africa.

On the center of the long border, a figure stands in front of an aedicule with two steps. In both sides of this figure, lions are running in opposite directions. This standing figure in front of the aedicule is reminiscent of the diagram known from the scenes of the raising of Lazarus. ${ }^{61}$ On the edge of this border is a naked figure with hands raised inside a kantharos. This scene could be symmetrically placed on both corners. The example at the Benaki Museum has partially distinguishable running lions on both sides of the aedicule, and a kantharos in front of them. ${ }^{62}$ A symmetrical arrangement was proposed in a restoration based on the examples at the Benaki Museum and a fragment in Berlin (fig. 8). ${ }^{63}$ However, the figure inside the kantharos is not visible in this restoration. Depiction of a figure in a kantharos survived on another fragment found in Nicotera, like the one in Andriake. ${ }^{64}$ We are unable propose a decoration for the shorter borders of the Andriake plate. Provided that longer borders had symmetrical decorations, an approximate length of $47-48 \mathrm{~cm}$ can be proposed for a longer border of the Andriake plates. Based on their analogs and the inscription, it can be suggested that the central decoration on the Andriake plate was a depiction of the Dioscuri.

As Christianity spread around the area where these vessels were produced, Christian buildings as well as pagan structures, such as those related to the cult of Bacchus, were located near each other. ${ }^{65}$ So it may be possible to observe Christian concepts together with pagan traditions and decorative elements on these productions. The Andriake fragments came from a North African workshop as a gift for a special occasion, like other ivory and silver plates of the era.

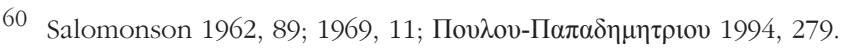

61 Sagui and Tortorici 1981, 175.

62 Salomonson 1962, pl. XXI.1; Fotopoulos and Delivorrias 1997, no. 285.

63 Salomonson 1962, fig. 4.

64 Cuteri et al. 2014, fig. 14.3b.

65 Allais points out that similar kantharos and vine depictions are seen in pagan depictions as well as church mosaics during the same period. In an evaluation of the decorative elements on the Pegasus-depicted plate found in Djemila, he considers that it could be in reference to the belief in Bacchus or a reflection of the concept behind the Christian decorations (Allais 1959, 51, 58).
} 


\section{Bibliography}

Akkurnaz, F.B. 2016. Eski Yunan ve Roma: Kaplar-Işlevler. Istanbul: Arkeoloji ve Sanat Yayınları.

Akyürek, T.E. 2016. "Andriake: The Port of Myra in Late Antiquity." In Trade in Byzantium. Papers from the Third International Sevgi Gönül Byzantine Studies Symposium, edited by P. Magdalino, N. Necipoğlu, and I. Jevtić, 465-87. Istanbul: Koç University Press.

Allais, Y. 1959. "Plat de Djemila à décor Mythologique.” Libyca 7:43-58.

Aygün, Ç.A. 2016. Andriake Mureks Boya Endüstrisi / Andriake Murex Dye Industry. Adalya Suppl. 14. Antalya: Koç University AKMED.

Aygün, Ç.A. 2018. "Myra'nın Limanı Andriake'nin Yerleşim Planı.” Ph.D. diss., Akdeniz University.

Bailey, D.M. 1998. Excavations at El-Ashmulein. Vol. 5, Pottery, Lamps and Glass of the Late Roman and Early Arab Periods. London: British Museum Press.

Buckton, D. 1994. Byzantium: Treasures of Byzantine Art and Culture in the British Collections. London: British Museum Press.

Bulut, S., and M. Şengül. 2010. "2009-2010 Y1lı Andriake Kazılarında Bulunan Sikkeler Üzerine Ön Rapor." Arkeolojisinden Doğasına Myra/Demre ve Çevresi, edited by N. Çevik, 119-25. Antalya: Kültür ve Turizm Bakanlı̆̆1.

Carandini, A., and E. Tortorici. 1981. "Produzione C3 e C4 decorata a relievo applicato a matrice." In EAA Vol. 1, Atlante delle forme ceramiche I ceramica fine romana nel bacino Mediterraneo (medio e tardo impero), 156-63. Rome: Istituto della Enciclopedia Italiana.

Cuteri, F.A., M.T. Ianelli, P. Vivacqua, and T. Cafaro. 2014. "Da Vibo Valentia a Nicotera. La Ceramica Tardo Romana Nella Calabria Tirrenica." LRCW 4 Late Roman Coarse Wares. Cooking Wares and Amphorae in the Mediterranean. Archaeology and Archaeometry. The Mediterranean: A Market without Frontiers. Vol. 1, edited by N. Poulou-Papadimitriou, E. Nodarou, and V. Kilikoğlu, 63-79. BAR-IS 2616 (1). Oxford: Archaeopress.

Çevik, N., and S. Bulut. 2010. "İkinci Kazı Sezonunda Myra ve Limanı Andriake." In Arkeolojisinden Doğasına Myra/Demre ve Çevresi, edited by N. Çevik, 25-118. Antalya: Kültür ve Turizm Bakanlığ1.

Çevik, N., Ö. Çömezoğlu, H.S. Öztürk, and İ. Türkoğlu. 2010. "A Unique Discovery in Lycia: The Ancient Synagogue at Andriake, Port of Myra." Adalya 13:335-66.

Çevik, N., S. Bulut, and Ç.A. Aygün. 2014. "Myra'nın Limanı Andriake." In Harbors and Harbor Cities in the Eastern Mediterranean from Antiquity to the Byzantine Period. Vol. 1, edited by S. Ladstätter, F. Pirson, and T. Schmidts, 225-43. Byzas 19. Istanbul: Ege Yayınlar1.

Delemen, İ., and S. Çokay Kepçe. 2009. Yunan ve Roma Kap Formları Sözlüğü. Istanbul: Türk Eskiçă̆ Bilimleri Enstitüsü.

Erhat, A. 1989. Mitoloji Sözlüğü. Istanbul: Remzi Kitabevi.

Fotopoulos, D., and A. Delivorrias. 1997. Greece at the Benaki Museum. Athens: Benaki Museum.

Fulford, M.G., and D.P.S. Peacock. 1984. Excavations at Carthage: the British Mission. Vol. 1.2, The Avenue du President Habib Bourguiba, Salammbo: The Pottery and Other Ceramic Objects from the Site. Sheffield: The British Academy.

Garbsch, J.von. 1980. "Spätantike Keramik aus Nordafrika in der prähistorischen Staatssammlung." Bayerische Vorgeschichtsbältter 45:155-97.

Garbsch, J.von. 1989. "Zwei Model und Eine Patrize für Mittelfelder spätantiker nordafrikanischer Tontablets.” Bayerische Vorgeschichtsblätter 54:243-49.

Guggisberg, M.A. ed. 2003. Der spätrömische Silberschatz von Kaiseraugust: Die neuen Funde. Forschungen in Augst 34. Basel: Schwabe \& Co.

Harris, J.R. 1906. The Cult of the Heavenly Twins. Cambridge: Cambridge University Press. 
Hayes, J.W. 1972. Late Roman Pottery. London: British School at Rome.

Kazdhan, A.P., and A.M. Talbot. 1991. "Dioskouroi." The Oxford Dictionary of Byzantium. Vol. 1, edited by A.P. Kazdhan et al., 633. New York/Oxford: Oxford University Press.

Mackensen, M. 2004. "Tonpatrizen und Vorlagen figürlicher Darstellungen auf spätantiken nordafrikanischen Sigillataplatten der Form Hayes 56." KölnJb 37:791-804.

Mackensen, M. 2015. "Die spätrömische Pegasus Platte Hayes 56 aus den sogenannten Heilthermen in den canabe legionis von Carnuntum.” ÖJh 84:195-212.

Magie, D. 1950. Roman Rule in Asia Minor. Vol. 1. Princeton/New Jersey: Princeton University Press.

Perna, R., C. Capponi, and V. Tubaldi. 2010. "Primi dati sulle ceramiche comuni, da fuoco e sulle anfore provenienti dagli scavi di Hadrianopolis (Softratike-Albania)." LRCW 3 Late Roman Coarse Wares. Cooking Wares and Amphorae in the Mediterranean. Archaeology and Archaeometry. Comparasion Between Western and Eastern Mediterranean. Vol. 2, edited by S. Menchelli et al., 731-39. BAR-IS 2185. Oxford: Archaeopress.

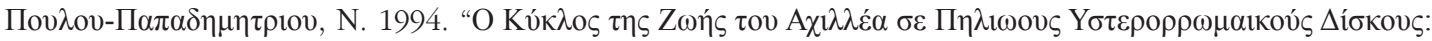

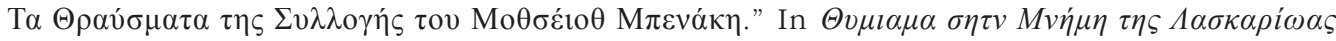

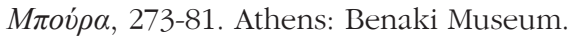

Sagui, L., and E. Tortorici. 1981. "Elenco dei motivi decorativi a rilievo applicato delle produzioni A e C." In $E A A$. Vol. 1, edited by G.P. Carratelli et al., 165-76. Rome: Istituto della Enciclopedia Italiana.

Salomonson, J.W. 1962. "Late Roman Earthenware with Relief Decoration Found in Northern Africa and Egypt." Oudh Meded 43:53-95.

Salomonson, J.W. 1969. "Spätrömische rote Tonware mit Reliefverzierung aus nordafrikanischen Werkstätten. Entwicklungsgeschichtliche Untersuchungen zur Reliefgeschmückten Terra Sigillata Chiara "C"”. BABesch 44:4-109.

Takmer, B. 2007. "Lex Portorii Provinciae Lyciae: Ein Vorbereicht über die Zollinschrift aus Andriake aus neronischer Zeit." Gephyra 4:165-88.

Tekinalp, V.M. 2000. "Geç Antik Dönem Sonrasında ve Ortaçă̆'da (M.S. 4-14. yy.) Andriake Kenti.” Ph.D. diss., Hacettepe University.

Tekinalp, V.M. 2001. "Andriake Kiliseleri ve Tarihlendirme Sorunlar1.” In V. Ortaçăg ve Türk Dönemi Kazı ve Araştırmalar Sempozyumu: Bildiriler (19-20 Nisan 2001), edited by S. Alpaslan, 491-516. Ankara: Hacettepe Üniversitesi Edebiyat Fakültesi.

Makale Geliş / Received : 30.10.2019

Makale Kabul / Accepted : 03.05.2020 


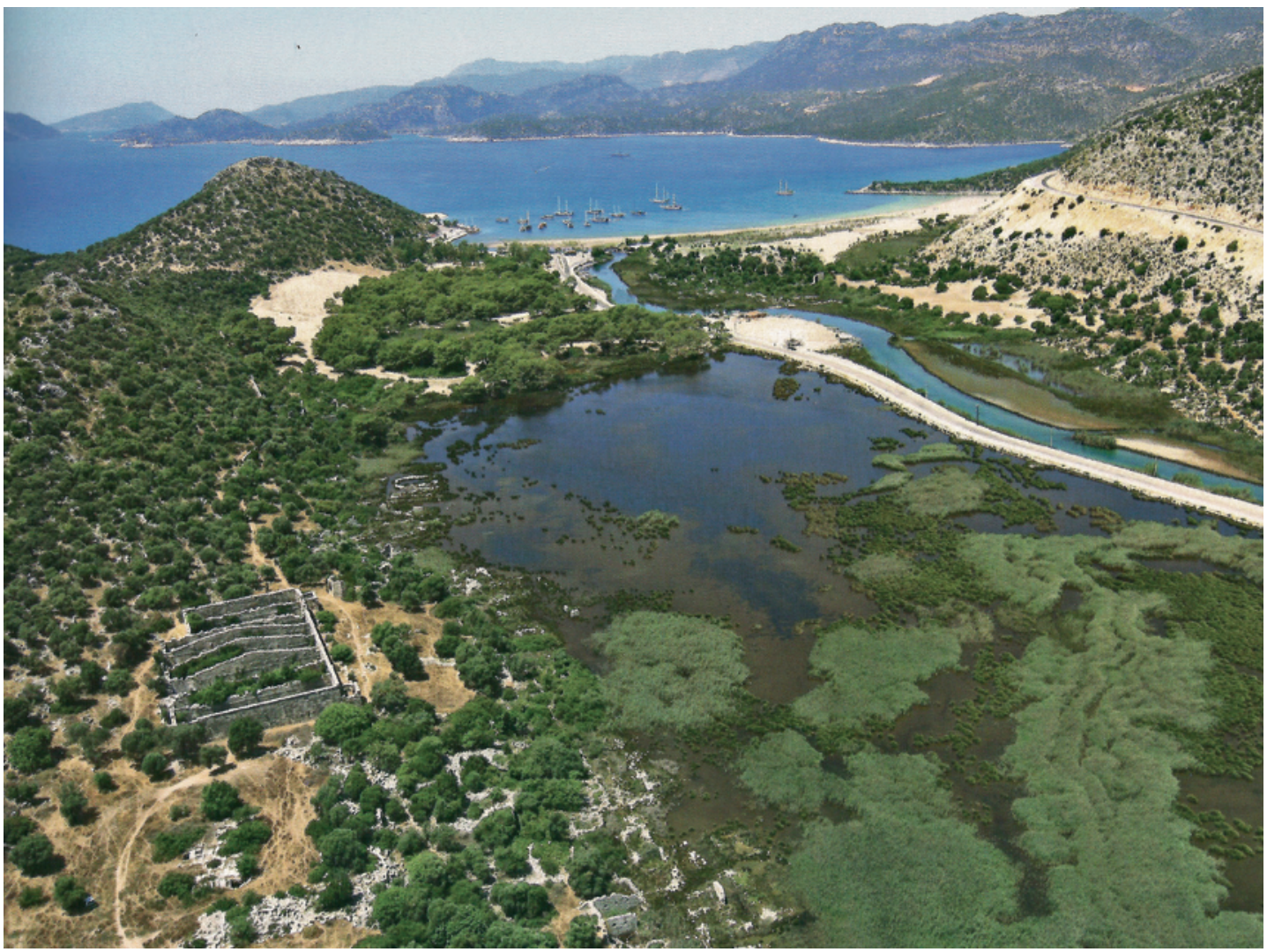

FIG. 1 General view of Andriake (Myra-Andriake Excavation archives).

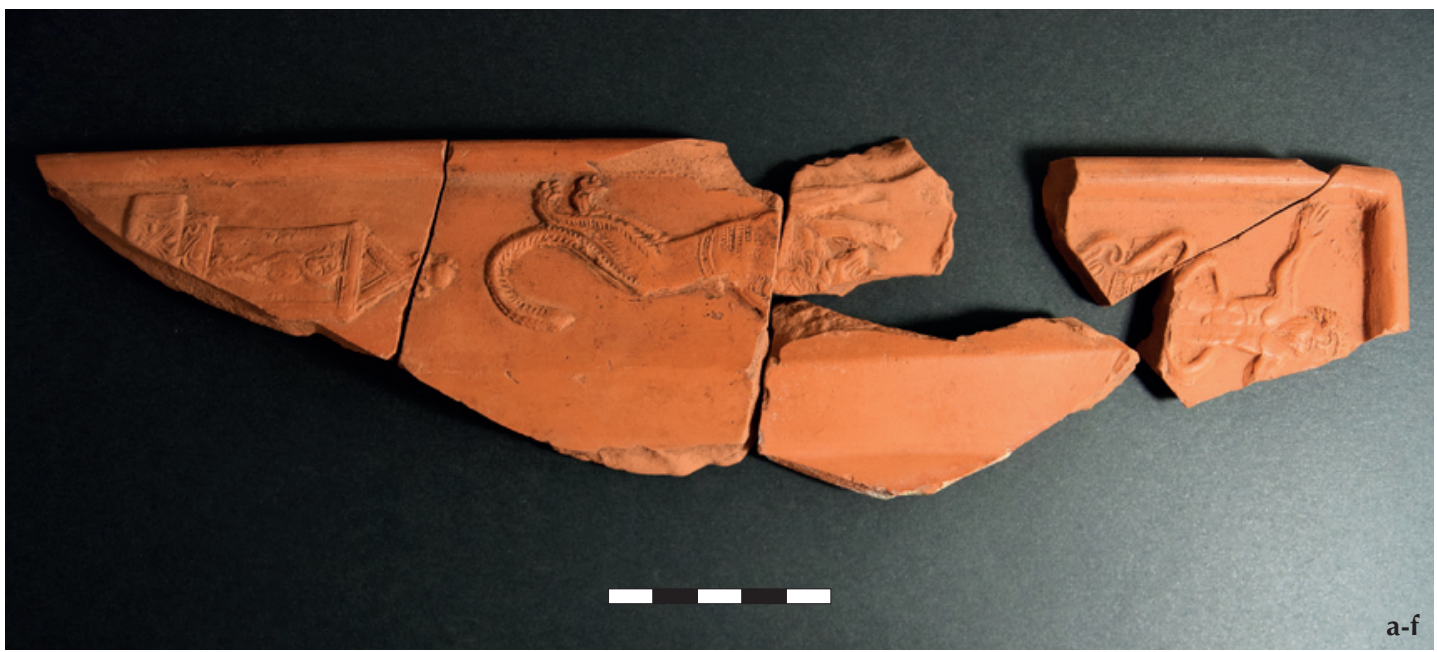

FIG. 2 Fragments, a-f. 

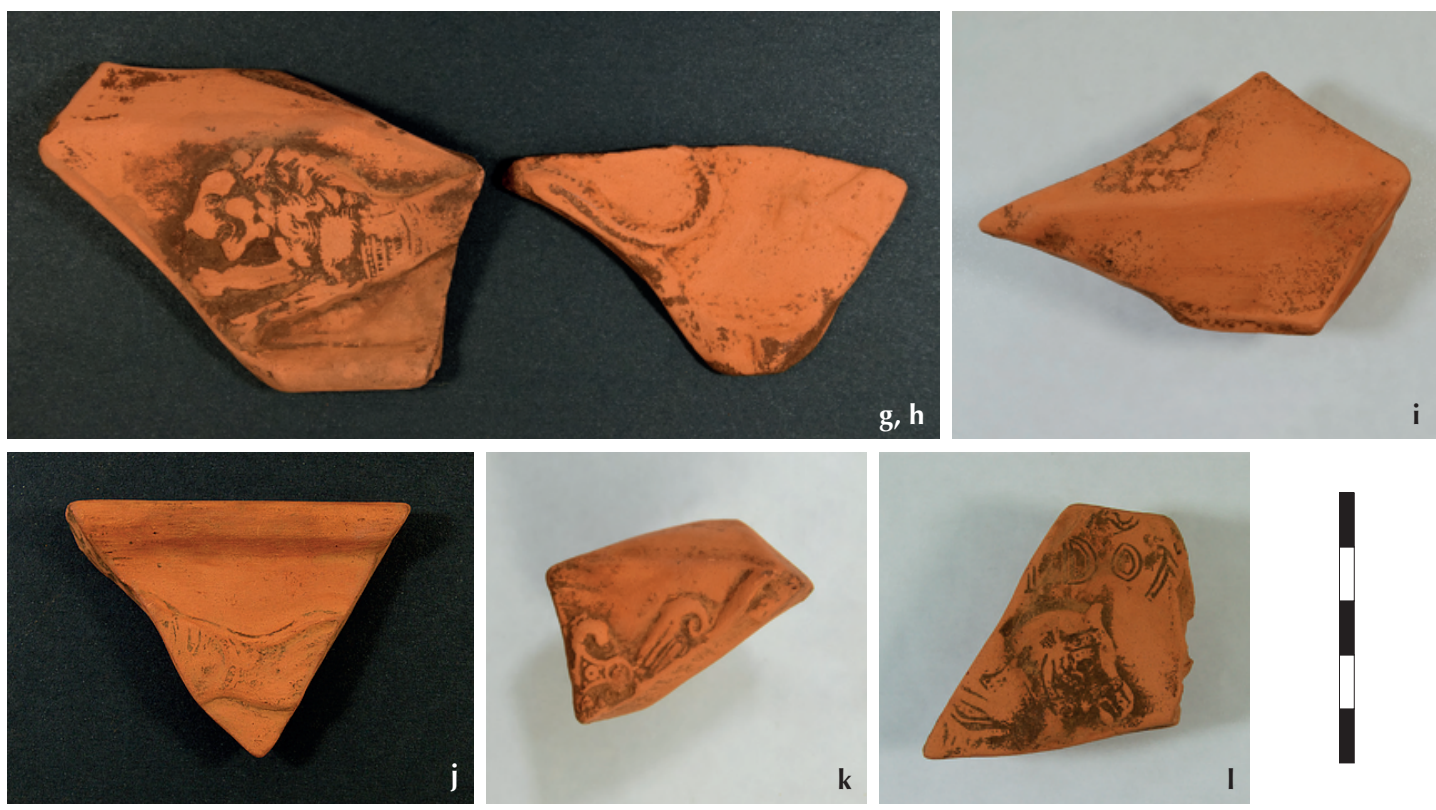

FIG. 3 Fragments, g-l.

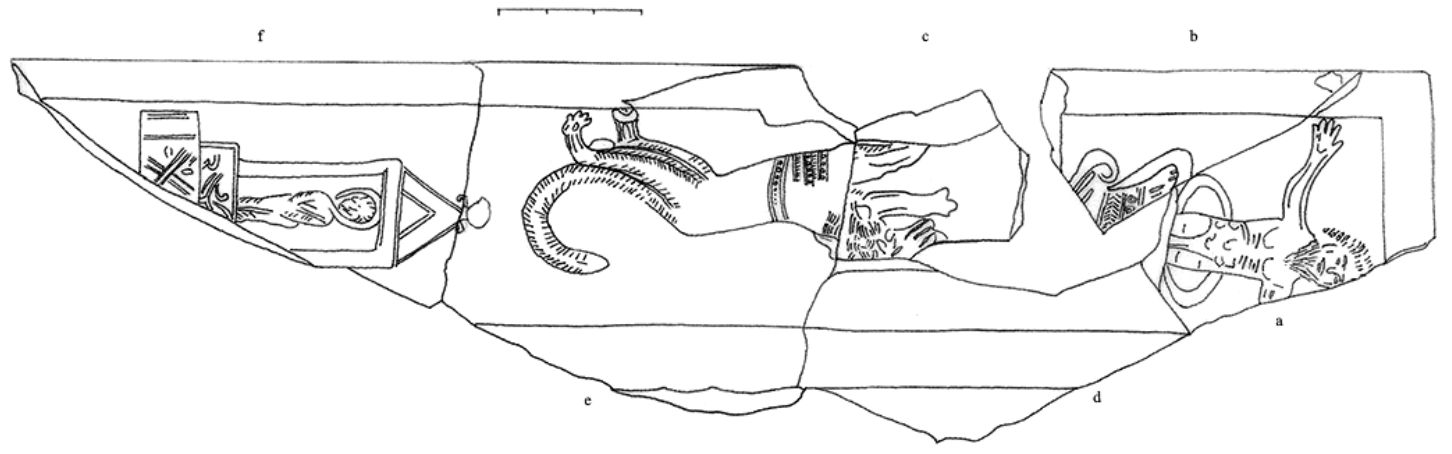

FIG. 4 Fragments, a-f.

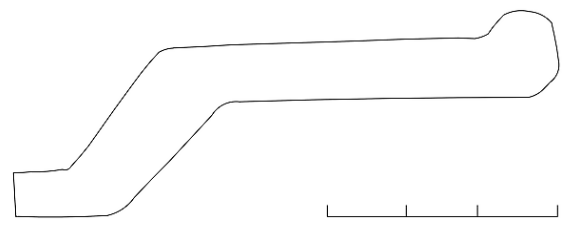

FIG. 5 Fragments, a-f (cross section). 

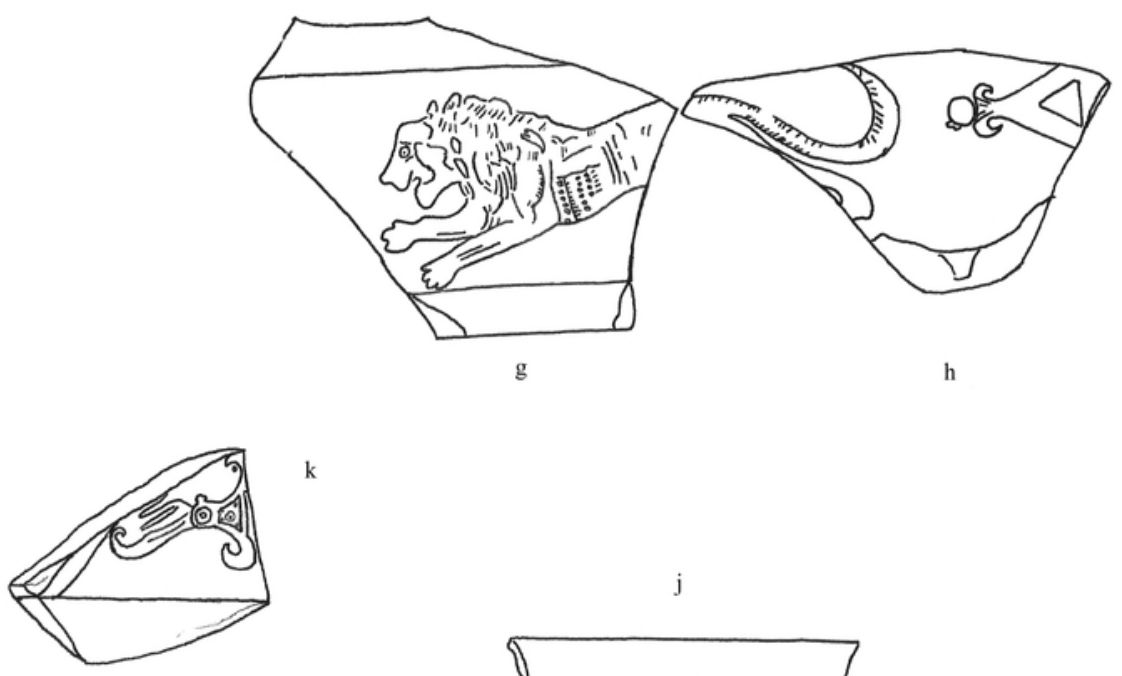

j
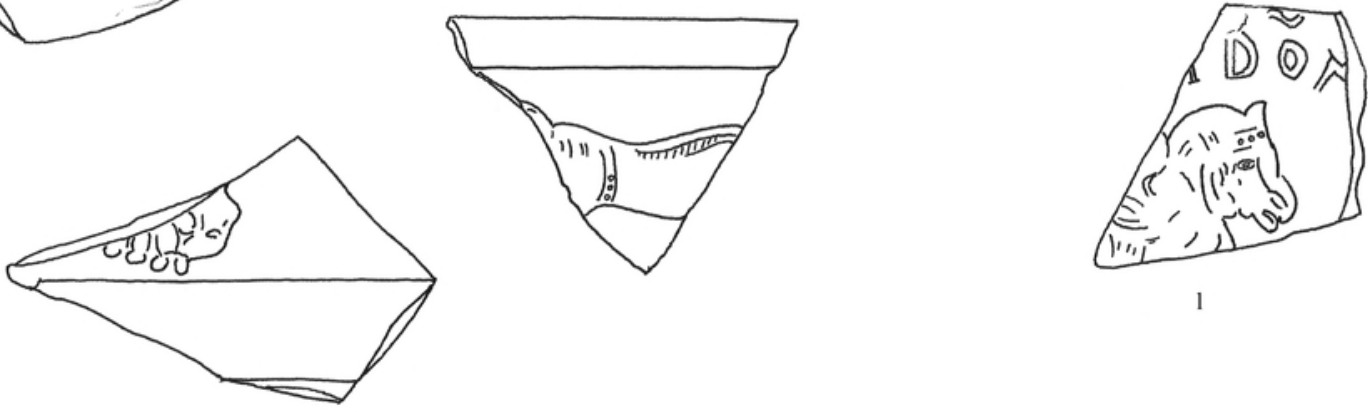

FIG. 6 Fragments, g-I.

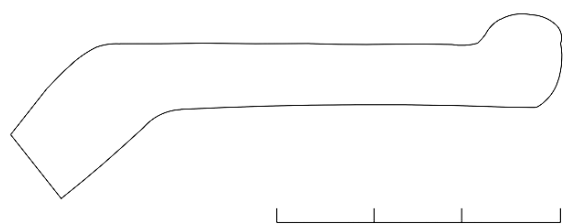

FIG. 7 Fragments, g-I (cross-section). 


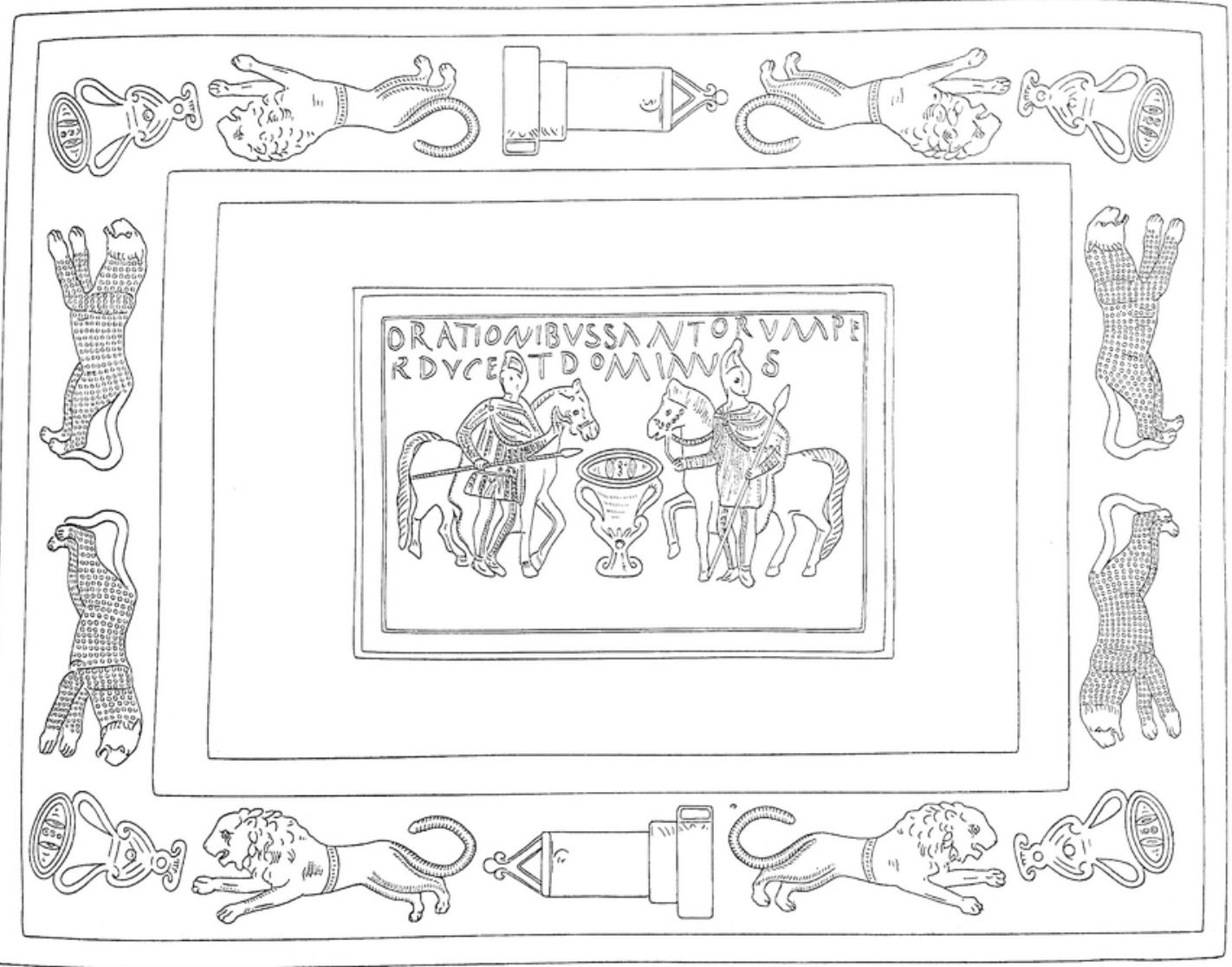

FIG. 8 Salomonson 1962, fig. 4. 
